\title{
Can Photodynamic Therapy Be an Alternative Method in Melanoma Treatment?
}

\author{
Anna Choromańska, Julita Kulbacka, Agnieszka Chwiłkowska, \\ Nina Skołucka, Andrzej Gamian and Jolanta Saczko \\ Wroclaw Medical University, Department of Medical Biochemistry, Wroclaw, \\ Poland
}

\section{Introduction}

Photodynamic therapy (PDT) is an effective cancer treatment that is an alternative to local therapy including surgical treatment and radiotherapy or systemic treatment such as chemotherapy or some kinds of immunotherapy. In many patients with cancer these therapeutic methods are not efficient or put their life at serious risk.

The principle of PDT is based on a photochemical process involving the absorption of light by a photosensitizer and the subsequent generation of reactive oxygen species (ROS) that induces cytotoxicity.

In the body, photosensitizers accumulate particularly in cancer cells. The precise reason for this preferential uptake or retention by malignant tissue is still unclear, but properties that appear to be involved include activated cellular uptake by neoplastic cells, differences in proliferation rates between neoplastic and normal cells, leaky vasculature within neoplastic tissue, and variations in mitochondrial potential. Moreover, PDT is a selective treatment because light delivery can be restricted to specific regions, thereby limiting activation of the drug to cured areas. These conditions mean that PDT is a safe treatment in comparison with other local treatments such as ionizing radiation and thermal destruction of tissue.

Oxygen-dependent photodynamic reactions were first described by Oscar Raab (Allison, 2010). He noted that an acridine solution killed paramecia upon irradiation with light. There was no such effect observed in the absence of light. On the basis of this knowledge about photodynamic effects, H. Tappeiner and H. Jesionek performed the first PDT sessions on a patient with skin carcinoma, with eosin as a photosensitizer (Allison, 2010). Since that time PDT has made considerable progress; new photosensitizers have been discovered and the procedure of therapy has been established.

\subsection{Mechanism of action}

The procedure of PDT requires two steps: administration of a photosensitizer, and its activation by light in the presence of oxygen in the tissue. Photosensitizers used in PDT should be nontoxic in their native state, but after excitation they become cytotoxic and produce local tissue destruction through intercellular generation of ROS. The light induces excitation of the photosensitizer molecules to the singlet excited state, which can be converted into the triplet excited state. The triplet state may react with surrounding 
molecules in two types of photo-oxidative reaction. Type I involves electron or hydrogen atom transfer, producing radical forms of the substrate which may react with oxygen to form peroxides, superoxide ions, and hydroxyl radicals. Type II leads to the generation of singlet molecular oxygen $\left({ }^{1} \mathrm{O}_{2}\right)$. Both mechanisms may occur simultaneously (Lukšienè, 2003). It is known that ${ }^{1} \mathrm{O}_{2}$ can diffuse only $20 \mathrm{~nm}$ during its lifetime (Peng, 1996); hence the primary damage is closely related to the site of its formation. Therefore, cellular structures having both a high sensitizer and a high oxygen concentration will be preferentially damaged upon illumination.

In PDT also occurs a third type of reaction. In contrast to the other two it is independent on the dissolved oxygen in the tissue. In contrast to the other two it is independent of the dissolved oxygen in the tissue. The photosensitizer in the singlet excited state can react directly with biomolecules, inducing a process of photoadduct formation (Capella et al., 2003). However, this mechanism is often ignored because the electron transfer between a biomolecule and photosensitizer, and formation of free radicals, is not effective (Ochneser 1997).

\subsection{Photosensitizers in PDT}

The main features of an efficient photosensitizer are: low toxicity at therapeutic doses in darkness, highly tumor-targeting accumulation, homogeneous composition and stability, and absorption peaks in the low-loss transmission window of biological tissues (the far-red and near-infrared regions). An effective photosensitizer is characterized by a high quantum yield of singlet oxygen generation and/or electron transfer to substrate molecules (Granville, 2001, Lukšienè, 2003). Good photosensitizer qualities are high solubility in water, availability, uncomplicated manufacture and synthesis.

Most photosensitizers applied in PDT are based on porphyrins. The most common photosensitizers are haematoporphyrin derivatives (HPD). Its theirs purified version named Photofrin, has an absorption peak in the red wavelength region at about $630 \mathrm{~nm}$. The first compound in the porphyrin synthesis pathway (5-aminolevulinic acid, 5-ALA) is also used in PDT. 5-ALA is converted in vivo into the photosensitizing compound protoporphyrin IX. The second generation of photosensitizers includes compounds from other chemical groups. Most of them are cyclic tetrapyrroles consisting of substituted derivatives of porphyrin, chlorin and bacteriochlorin. Many research centers are developing new and quite different molecular structures that can act as the ideal photosensitizer (Granville, 2001).

\subsubsection{Light}

The photodynamic reaction is dependent on the delivery of light of an appropriate wavelength to activate a photosensitizer. The light used for photosensitization is typically in the visible or near-infrared light range. In general, with increasing wavelength in the visible and near-infrared range the depth of penetration of light increases and the absorption by hemoglobin and other endogenous chromophores decreases (Smith, 2002).

Application in PDT of higher wavelengths of light enables treatment of heavily pigmented tissues (Woodburn, 1998). Good light sources in PDT are metal halogen lamps, which emit from 600 to $800 \mathrm{~nm}$ radiation at high power density, and short-arc xenon lamps, tunable over a bandwidth between 400 and $1200 \mathrm{~nm}$ (Lukšienè, 2003).

The popularization of laser technology with optical fibers facilitates photosensitization in clinical treatment. Lasers enable the precise endoscopic application of light to almost every 
site of the human body and allow the exact selection of wavelengths. Pulsed lasers, such as the gold vapor laser (GVL) and the copper vapor laser-pumped dye laser, produce brief light pulses of millisecond to nanosecond duration (Fisher 1995). Tunable solid-state lasers, such as the neodymium: YAG laser, are particularly useful for PDT. Portable semiconductor diode lasers, such as the gallium-aluminum-arsenide laser, produce light in the range from 770 to $850 \mathrm{~nm}$, which corresponds to the absorption peaks of many new photosensitizers (Lukšienė, 2003).

\section{Cell damage after PDT}

The antitumor activity of PDT is based on four mechanisms: direct cytotoxicity, which is an intermediate reaction of singlet oxygen production with subsequent oxidation of the substrate, occlusion of blood vessels and lymphatics, and the impact on the immune response and inflammation of the body (Krawczyk-Krupka et al., 2001, Sieron \&Adamek, 1999, Mazur et al., 2010). Generated reactive oxygen species (ROS) cause oxidative stress in the cells (Dellinger, 1996). The oxidative stress damage is targeted mainly at cellular macromolecules, such as lipids, nucleic acids and proteins. Hydrophobic photosensitizers accumulate mainly in cell membranes and they are primarily attacked by free radicals.

\subsection{Oxidative stress}

Oxidative stress is an imbalance between the formation of reactive oxygen species (ROS) and antioxidant mechanisms. Free radicals in living organisms may result from the action of endogenous factors (e.g. respiratory chain, activated leukocytes, inflammation, enzymes) or exogenous (e.g. cigarette smoke, alcohol, intense physical activity, UV radiation, ionizing radiation, car exhaust, contaminated air, physical and psychological stress). In physiological conditions the release of free radicals is controlled by the body's defense mechanisms (Sheu et al., 2006). Free radicals play a crucial role in cell functions including proliferation, apoptosis, inactivation of the growth of bacteria and viruses, intracellular signaling and intercellular communication. ROS have effects that augment or shrink the blood vessel walls, and stimulate glucose transport into cells. Disorder of the defense mechanisms under the influence of external factors or disease causes an increase in free radicals in the body, and consequently the occurrence of pathological reactions leading to damage to cells and tissues (Gałecka et al., 2008, Łagowska-Lenart et al., 2008). In vitro studies show that the destructive action of free radicals may include all biomolecules in the body, causing chemical modifications and damage to proteins (denaturation), lipids (peroxidation), carbohydrates and nucleotides, resulting in changes in the structure of DNA leading to mutations (Sheu et al., 2006, Bailey et al., 2005). The concentration of oxidation products (e.g. carbonyl groups) reflects the intensity of the reaction involving reactive oxygen species. An antioxidant barrier protects the organism from the damaging effects of reactive oxygen species.

\subsection{Lipid peroxidation}

Lipid peroxidation (LPO) is a free radical process of oxidation of polyunsaturated fatty acids or other lipids. Lipid peroxidation proceeds in three major steps: initiation, propagation, and termination. During the first stage a fatty acid radical is produced. The hydroxyl radical is identified as initiating lipid peroxidation by abstracting hydrogen atoms from fatty-acid side chains. Cell membranes contain unsaturated fatty acids that are readily attacked by 
reactive oxygen species. LPO can be initiated by hydroxyl radical $(\bullet \mathrm{OH})$, superoxide radical $(\mathrm{LOO} \bullet)$, alkoxy radical $(\mathrm{LO} \bullet)$, alkyl radical $(\mathrm{L} \bullet)$, as well as ozone $\left(\mathrm{O}_{3}\right)$, nitrogen monoxide and dioxide, sulfur dioxides, and hypochlorite (Shevchuk et al., 2002, Bartosz, 2003).

During the propagation phase, free alkyl radicals $(\mathrm{L} \bullet$ ) react with molecular oxygen to form peroxyl free radicals $(\mathrm{LOO} \bullet$ ). They may also detach hydrogen atoms from subsequent molecules of polyunsaturated fatty acids (LH). This cycle continues, as the new fatty acid radical reacts exactly in the same way until the termination reaction. The stage of termination occurs when a radical reacts with a non-radical. It is a "chain reaction mechanism" because a new radical is always produced. The radical reaction stops when there is such a high concentration of radical species that it can cause the impact of two radicals, forming a non-radical.

The final products of lipid peroxidation are hydroxy aldehydes (e.g. 4-hydroxynonenal), hydrocarbons (e.g. ethane and pentane) and aldehydes (e.g. malonic dialdehyde - MDA) an endogenous genotoxic compound (Bartosz, 2003, Kessel et al., 1997, Hsieh et al., 2003). Increased production of reactive oxygen species induces an increase of lipid peroxidation products. These LPO products are able to modify the physical properties of cell membranes, leading to a loss of integrity of intracellular membranes by depolarization, increased permeability to $\mathrm{H}$ - ions, disruption and inhibition of the activity of the asymmetry of membrane enzymes and transport proteins (Hsieh et al., 2003).

\subsection{Protein degradation under the influence of oxidative stress}

Oxidative changes are an inherent effect of cellular metabolism and can not be eliminated. Accumulation of oxidized protein products impairs cell functions and can even induce cell death (Plaetzer 2003). ROS can induce oxidation of protein thiol groups (-SH) and form thiol radicals $\left(S^{*}\right)$. The most degenerating for the cell during oxidative stress is oxidation of thiols in the membrane. It can lead to membrane disintegration and increased permeability. Oxidative damage of - $\mathrm{SH}$ groups causes rapid loss of biological activity of protein. These radicals in turn oxidize to disulfides, forming intermolecular disulfide bridges. These reactions cause irreversible changes in membrane structures, which are dangerous to the life of the cell (Wang 2001).

\subsection{Changes in DNA}

DNA encodes genetic information, so any changes that occur in the genome are extremely dangerous for the cell. The number of daily incidents of DNA damage exceeds 10000 ; therefore there are corrective mechanisms for sensing and correcting the damage. The mechanisms of DNA damage induced by photodynamic therapy are not well known. PDT can cause cross-linking of DNA strands (McNair et al., 1997, Haylett et al., 2003, Woods et al., 2004). DNA damage caused by photodynamic therapy may occur in cancer cells and normal cells surrounding the tumor. PDT generates through the photosensitizer reactive oxygen species. Singlet oxygen has a very limited range $(<0.1 \mu \mathrm{m})$ and life-span (less than 1 s). The probability of DNA damage is low, unless it is generated in the close proximity of a DNA strand. Current studies suggest that cell death after PDT is caused by damage to cytoplasmic proteins and mitochondria, and not damage to DNA (Miller et al., 2007). Normal cells are able to cope with the damage after PDT but this is dependent on the type of photosensitizer (Woods et al., 2004). 


\subsection{Antioxidative system}

To protect against free radical damage the body uses a number of mechanisms to provide antioxidant protection of the body. Structural cell organization is one of these mechanisms. This specific formation enables isolation of those places where free radical reactions take place (Halliwell, 2000, Huang, 2000). In addition various metabolic mechanisms play an important role in protection against free radicals. The knowledge of oxidative damage caused by PDT is important in developing strategies for treating tumours and the potential reduction of side effects. They have been divided into the following categories (Santiard, 1995):

- Reactions with suppressive compounds (carotenoids, vitamin E);

- Non-enzymatic mechanisms: antioxidants, free radical scavengers, ions of transition metals, sequestration of metals, metallothioneins;

- Enzymatic mechanisms: superoxide dismutase, catalases, heme oxygenase, glutathione peroxidase, glutathione reductase, glutathione S-transferase and groups of secretory phospholipases $\mathrm{A}_{2}$;

- $\quad$ Reactions with heat shock proteins - proteases and chaperone proteins.

\subsubsection{MnSOD}

MnSOD is a mitochondrial form with $\mathrm{Mn}$ in the active center. Human MnSOD is a tetrameric enzyme with four identical subunits each harboring a $\mathrm{Mn}^{+3}$ atom (McCord, 2002). It was demonstrated that transient transfection with the MnSOD gene resulted in decreased effectiveness of PDT. These results suggest that MnSOD plays a leading role in the response to PDT and that abnormal mitochondria may be a decisive factor in phototoxicity (Saczko et al., 2007). MnSOD is a critical antioxidant enzyme residing in mitochondria. Golab et al. observed that following PDT there was induction of MnSOD expression in tumor cells (Golab et al., 2003). The group of SODs is emerging as significant antioxidative enzymes that can regulate the sensitivity of cancer cells to different treatment modalities. Some authors have also observed that overexpression of MnSOD suppresses apoptosis (Kuroda et al., 2000).

\subsubsection{Heme oxygenase-1 (HO-1)}

Heme oxygenase exists in two isoforms: inducible (HO-1) and constitutively expressed (HO2). Heme oxygenase-1 (HO-1) is an enzyme that catalyzes the degradation of heme to $\mathrm{Fe}^{2+}$ ion, carbon monoxide and biliverdin, and then biliverdin is converted to bilirubin by biliverdin reductase (Dulak \& Jozkowicz, 2003). Biliverdin and bilirubin are antioxidants, and may therefore play a very important role in cytoprotection of cells exposed to the oxidative stress induced by PDT. Induction of HO-1 by PDT was described in the CHO (Chinese hamster ovary) cell line using Photofrin (Gomer, 1991). The photodynamic reaction induces HO-1 expression. HO-1 also plays a protective role in cells where PDT was applied. The removal of iron ions with desferrioxamine from cells after PDT resulted in increased cell death, which confirms the key role of ferrous ion generation in HO-1 mediated cytoprotection (Nowis et al., 2006).

\subsubsection{Heat shock proteins}

The heat shock proteins (HSPs) are a class of proteins whose expression is increased when cells are exposed to different kinds of stress such as heat shock, $\mathrm{pH}$ shift, hypoxia, osmotic 
and oxidative stress. Production of HSPs may also grow in response to infection, inflammation, effects of toxins, UV radiation, starvation, etc. HSPs work as chaperone proteins responsible for the proper folding of other proteins, translocation and degradation. They also participate in protein assembly, export, turnover and regulation. HSPs are found in virtually all living organisms. In normal conditions cellular levels of HSPs are stable and low, but if cells are exposed to any kind of stress, the levels of HSP quickly increase (Pockley, 2003). HSPs are generally classified according to their molecular weight, which can vary from 10 to $170 \mathrm{kDa}$, e.g. HSP70 (Hightower \& Hendershot, 1997). PDT induces different HSPs including HSP27, HSP60, HSP70, HSP90, GRP78 and GRP94. A protective role in PDTtreated cells has been shown, for example survival of tumor cells exposed to PDT induced overexpression of HSP27 (Wang et al., 2002). When there are damaged proteins, HSP binds damaged molecules. This results in dissociation of HSF (heat shock factor), then migrates to the nucleus, where it binds with HSE (heat shock elements) leading to HSP overexpression (Morimoto, 1993). HSP90 inhibits formation of an active apoptosome whereas HSP70 prevents the recruitment of procaspase- 9 to the apoptosome complex (Almeida et al., 2004).

\subsubsection{GSTT}

Glutathione S-transferases (GSTs) are crucial in protection of cells against oxidation products. There are enzymes of the second phase of metabolism that counteract the process of carcinogenesis (L'Ecuyer 2004). This group of enzymes plays a key role in detoxification and reduction of reactive oxygen forms, especially the isoform GST-pi. This enzyme protects cells against DNA disintegration and drug toxicity. Genetic polymorphisms in glutathione S-transferase and its altered expression and activity are associated with oxidative DNA damage which in turn leads to increased susceptibility to cancer (L'Ecuyer al., 2004). A high level of GST-pi expression is related to the development of drug resistance in cancer cells not only by increased detoxification of anticancer agents, but also by suppression of cellular ROS which induce cell death. This means that a high level of GST-pi may be a prognostic factor in malignant diseases (Aliya et al., 2003).

\subsubsection{Small molecule antioxidants}

Molecular reactions of antioxidants with ROS are less specific than the effect of antioxidant enzymes, which means that these compounds are more versatile defenders. The body's antioxidant status is also dependent on the level of exogenous antioxidants, mainly supplied with food. An important role is played by vitamin E. Because of its lipophilic properties it may have a protective effect in relation to membrane phospholipids, protecting them from peroxidation. One free radical could trigger the whole cascade of reactions leading to oxidation of unsaturated fatty acids. This cascade proceeds until another formed fatty acid radical meets on their way vitamin $\mathrm{E}$, which breaks the chain reaction. Reduced vitamin $\mathrm{E}$ can be regenerated by vitamin $C$ that has the ability to stabilize the hydroxyl radical (Chow et al., 1999, Rahman, 2007, Sies et al., 1992). Vitamin C reacts with the hydroxyl radical and singlet oxygen. Vitamin $C$ with glutathione coenzyme $Q$, cysteine, uric acid and bilirubin are among the active antioxidants in the aqueous phase. Vitamin $C$ inhibits the peroxidation of hemoglobin and with coenzyme $Q$ and reduced glutathione protects mitochondria from oxidative damage (Kurl et al., 2002). The effect of vitamin E supplements $\beta$-carotene and its metabolite, vitamin A. The precursors of vitamin A include carotenoids, the main dietary source of vitamin A in humans. In the gastrointestinal tract arises retinal, which is then converted to retinol (Rahman, 2007, Sies et al., 1992). 


\section{Mechanism of cell death}

Oxidative stress is a factor which initiates cell death after photodynamic reaction (Almmeida et al., 2004, Castano et al., 2005, Kulbacka et al., 2010, Saczko et al., 2009). In this part of our review we will examine the mechanisms of cell death caused by ROS and related metabolites, which are stimulated during the photodynamic process. The type of cell death by PDT may be mainly apoptosis or necrosis depending on the properties and concentration of the photosensitizer connected with the irradiation dose. However, another mode of cell death was also observed after photodynamic treatment, i.e. autophagic. This type II cell death is characterized by an enormous increase of two-membrane autophagic vacuoles in the cytoplasm which are finally catalyzed by lysosomal hydrolases (Edinger et al., 2004, Kroemer et al., 2005, Golstein et al., 2006). Autophagy is a convertible process, which can provoke both survival and death pathways, in contrast to the apoptotic irreversible process leading only to cell death (Kessel et al., 2007). Apoptosis (type I cell death) is genetically and morphologically different from necrosis. Apoptosis represents a regulated, universal and perfectly efficient, strongly controlled energetic suicide pathway. This process requires the activation of some hydrolytic enzymes - proteases and nucleases - leading to DNA fragmentation and destruction of cell structures. The morphological changes connected with apoptosis include nuclear pyknosis, DNA fragmentation, membrane blebbing, cell shrinkage and production of apoptotic bodies which are removed by adjacent cells and resident phagocytes (Kroemer et al., 1998 and 2005, Ryter et al., 2007, Kroemer et al., 2007). Apoptotic cell death is the most preferable effect of various anticancer therapies which leads to destruction and elimination of pathological cells. Inflammation does not occur through apoptosis in cancer cells and surroundings tissue (Fiers et al., 1999). On the other hand, necrosis (type III cell death) appears in a negative way as death associated with gross membrane damage and cell outflow into the extracellular space. This characteristic modification may lead to local inflammation and injury of nearby tissue. The endpoint of necrosis is manifested in cell swelling or oncosis (Majno et al., 1995). However, a recent study showed that necrosis can also occur similarly to programmed cell death, which consists of induction, commitment and execution processes of necrosis triggering the cysteine cathepsin-mediated lysosomal death pathway (Leist et al., 2001, Bizik et al., 2004, Golstein et al., 2005, Golstein et al., 2006). In general, it can be observed that lower doses of PDT lead to apoptosis, while higher doses lead to necrosis in cells (Ketabchi et al., 1998, Kessel et al., 2000). A previous study showed that the three well-known types of cell death are dependent on the developmental stage, physiological conditions of cells and the nature of the death signal (Majno 1995). Mixed-type cell death forms, containing characteristic properties for both types, apoptosis and necrosis, have been noted (Wang et al., 2003).

\subsection{Apoptosis following PDT}

The photodynamic reaction activates different signal transduction pathways connected with transcription factors and cell cycle regulation, which often lead to cell death or survival (Pazos et al., 2007, Robertson et al., 2009). The different types of cell death-induced photodynamic processes are permanently under investigation. However, the majority of studies have shown that apoptosis is a rapid and dominant type of cell death following the photodynamic reaction, in different experimental conditions and a variety of sensitizers (Oleinick et al., 2001). On the other hand, cancer cells can die in other ways: necrosis or autophagy (Buytaret et al., 2006). Autophagic and programmed necrosis are rarely related to 
PDT. There are a few commonly known significant factors which can induce necrosis: extramitochondrial location of photosensitizers, a high dose of PDT, and glucose starvation (Almeida et al., 2004, Kieslich et al., 2005, Nowis et al., 2005). Also the cells' sensitivity to PDT conditions and their genotype may control the type of cell death following PDT (Wyld et al., 2001, Bar et al., 2007, Saczko et al., 2005). The most significant factors determining the effect of PDT are the physicochemical properties, intracellular distribution of photosensitizers, and the interactions between different cellular organelles such as mitochondria, lysosomes, endoplasmic reticulum (ER), Golgi apparatus and plasma membranes. The uptake of photosensitizers into cancer cells plays a decisive function in increasing the efficiency of PDT (Pazos et al., 2007, Robertson et al., 2009). Numerous studies with various first and second generation photosensitizers have concluded that the induction of apoptotic cell death by PDT was connected with mitochondrial damage (Kessel et al., 1998, Saczko et al., 2005 and 2007, Chwiłkowska et al., 2006). Kessel and other researchers have demonstrated that sensitizers which localize in mitochondria are much more rapid inducers of apoptosis than photosensitizers localized in endoplasmic reticulum, Golgi apparatus, lysosomes and plasma membranes (Kessel et al., 1997, Dahle et al., 1990, Marchal et al., 2004). On the other hand, cationic photosensitizers or others accumulating in plasma membrane were associated with membrane photodamage and necrotic results (Kessel 1998, Luo 1996). Moreover, the availability of oxygen, the suitable wavelength and intensity of light, as well as the biological conditions and type of cancer cells can influence the mode of cell death (Rosa et al., 2000, Castano et al., 2004, Juzeniene et al., 2007, Plaetzer et al.,2003).

Photodynamic therapy can induce apoptosis in two dissimilar pathways: intrinsic, mitochondria-dependent, and extrinsic, death receptor-dependent (Almeida et al., 2004).

\subsection{Intrinsic pathway}

Mitochondria play a crucial role in intrinsic pathways of apoptotic cell death, due to mitochondrial damage being the major object of photocytotoxicity. The mitochondrial pathway of apoptosis is often mediated when sensitizers are accumulated in these organelles, but it is not obligatory. The loss of mitochondrial transmembrane potential and the release of cytochrome $\mathrm{c}$ from the mitochondrial inner membrane space to the cytosol is a well-examined apoptotic occurrence, which has also been documented for numerous photosensitizers localized in mitochondria such as Photofrin, benzoporphin derivative, cyanine and phthalocyanine (Fabris et al., 2001, Pervaiz et al., 1999, Saczko et al., 2007). The present observation of apoptosis by the mitochondrial pathway shows that cytochrome $c$ released to the cytoplasm forms a triple complex with the apoptosis-inducing factor (Apaf1) and procaspase 9, which leads to activation of procaspase 9 and following activation of executioner caspases. Uncontrolled generation of reactive oxygen species during PDT can lead to endoplasmic reticulum stress. It results in perturbation of the $\mathrm{Ca}^{2+}$ gradient, which can lead to the creation of a permeability transition complex and the involvement of Bcl-2 proteins (Grebenova et al., 2003, Buytaret et al., 2006, Nowis et al., 2005). Some data show that the endoplasmic reticulum as well as mitochondria may induce apoptosis and autophagy in cancer cells following the photodynamic reaction. Manipulation of the PDT conditions results in suppression of apoptosis with increasing autophagy in mouse L1210 leukemia cells (Kessel et al., 2007). The hydrophilic chlorine photosensitizers localize mainly in lysosomes and activate the mitochondrial apoptotic pathway following photodamage of lysosomes. The lysosomal proteases are released by lysosomal injury during the photodynamic reaction and activate caspases directly or indirectly through mitochondrial 
damage. However, the mechanisms by which lysosome-localizing sensitizers induce mitochondrial apoptotic cell death are not fully elucidated (Nakajima et al., 1992, Mori et al., 2000, Nagata et al., 2003, Reiners et al., 2002).

\subsection{Activation of caspases}

The apoptosis effectors contain intracellular proteases termed caspases. Caspases are a family of intracellular endopeptidases that are synthesized as zymogens and are converted into active enzymes. Caspases can be divided into two groups: initiators (numbers 1, 2, 4, 5, 8, 9, 10 and 12) and effectors (numbers 3, 6 and 7) (Castano et al., 2005). The properties of apoptotic cell death are dependent on proteolytic cleavage of cellular substrates by effector caspases and can be activated by three dissimilar pathways involving intrinsic apoptosis activated by caspase 9, an extrinsic way connected with caspase 8 , and an endoplasmic reticulum stress one induced by caspase 12 .

The mitochondrial pathway is associated with release of cytochrome c proteins by mitochondria into the cytoplasm involving establishment of caspase 9 and cleavage of executioner caspases 3, 6 or 7 (Ketabchi et al., 1998, Robertson et al., 2007). This leads to degradation of various proteins and DNA and finally cell death by apoptosis. Some investigations suggest that high doses of photodynamic therapy can photochemically inactivate crucial enzymes and other components of the apoptotic cascade such as caspases (Lavie et al., 1999). A previous study examined the level of expression of caspase 3, 8 and 9 after photodynamic reaction with Photofrin ${ }^{\circledR}(\mathrm{Ph})$ using immunocytochemical assay (ABC method) in MCF-7 (human breast adenocarcinoma cell line) and A549 (human lung carcinoma cells). Differentiated expression of caspases 3, 8 and 9 in A549 cells was observed. The intensity of immunocytochemical staining of caspases depends on the concentration of Photofrin ${ }^{\circledR}$, the time of irradiation and the incubation time after irradiation. Detection of two initiators, caspases 8 and 9, after photodynamic reaction in human lung adenocarcinoma A549 cells may suggest that apoptosis activation occurs by two independent signal transduction pathways, which are relative (Fabris et al., 2001, Grebenova et al., 2003, Saczko et al., 2007). Also a mechanism has been documented in which caspase 8 cleaves Bid protein and there follows mitochondrial release of cytochrome c dependent activation of caspase 9 (Buggiani et al., 2008). Moreover, a variety of apoptosis activation pathways induced during the photodynamic reaction can result in a lot of alternatives and cross-link the apoptotic signal transduction pathway (Almeida et al., 2004, Mitsunga et al., 2007).

\subsection{Bcl-2 family proteins and p53 status}

The Bcl-2 family proteins are divided into two groups: antiapoptotic Bcl-2, Bcl- $\mathrm{X}_{1}$, and Bcl$\mathrm{w}$, and proapoptotic Bax, Bak, Bad, and Bim, which respectively inhibit or support the execution of apoptotic cell death. Thus families of proteins control mitochondrial stability by maintaining the balance between proapoptotic proteins that translocate to the mitochondria and antiapoptotic ones that exist in the mitochondrial membrane (Ryter et al., 2007, Kelekar et al., 1998). The Bcl-2 gene product is located in the membranes of the endoplasmic reticulum, nuclear envelope and the external membranes of the mitochondria (Ryter et al., 2007). The most significant objective of PDT in the cell signaling pathway is activation of the proapoptotic proteins belonging to the Bcl-2 family. Photodamage after photodynamic reaction provokes activation of these proteins and induces apoptosis in malignant cells. Bax protein expression has been linked to a beneficial reaction to PDT. It can be used to assess 
the cancer response to photodynamic reaction (Zhen-hui Peng et al., 2008, Roland et al., 2007, Robertson et al., 2007). Generally the role of Bax protein in the release of cytochrome c from mitochondria into the cytoplasm and activation of the apoptotic process has been established in many systems. Chiu and co-workers observed that phthalocyanine Pc-4-PDT induced Bax dislocation from the cytoplasm to mitochondria as early signaling for the mitochondrial pathway of apoptosis in human breast cancer MCF-7c3 cells (Chiu et al., 2003). Phthalocyanine Pc4 is a new generation sensitizer that localizes in intracellular membranes, particularly in mitochondria. Pc4-PDT photodamages antiapoptotic Bcl-2 and $\mathrm{Bcl}-\mathrm{xL}$ proteins and activates apoptosis in cancer cells (Castano et al., 2005, Kessel et al., 2000, Xue et al., 2001). Usada et al. examined the cells with transfection and wild-type Bcl-2. Overexpression of Bcl-2 decreased apoptosis, which is connected with inhibition of the proapoptotic Bax protein. On the other hand, high doses of Pc4-PDT are necessary to activate Bax in cells with increasing expression of antiapoptotic Bcl-2 protein (Usada et al., 2003). The p53 tumor suppressor gene takes part in the response to DNA damage, connected with cell cycle regulation, DNA repair, and induction of apoptosis (el-Deiry et al., 1998, Bunz et al., 1999). Expression of wild-type p53 activated by chemotherapy, radiation or photodynamic reaction increases the sensitivity to apoptosis, whereas mutated p53 decreases the sensitivity. In many cases of cancer, mutated p53 was found (Lowe et al., 1994). P53 plays a crucial role in regulation of proapoptotic Bcl-2 proteins. Bax induced the mitochondrial pathway by outflow of apoptogenic proteins, such as cytochrome c. However, in different studies the involvement of Bax and p53 in PDT-mediated apoptosis was observed (Fisher et al., 1997, Fisher et al., 1998, Zhang et al., 1999). Some data indicate that p53 is required for caspase 3 activation, suggesting that p53 may play a role in PDTactivated early apoptosis in cancer cells (Mitsunga et al., 2007). Bar and co-workers examined the effect of Photofrin-PDT (Ph-PDT) on clear human ovarian carcinoma with a "silent" mutation in the p53 gene. The cells were dying in a necrotic way. They postulated that this mutation can inhibit apoptosis in these cells (Bar et al., 2007). The modification of Ph-PDT by 2-methoxyestradiol leads to activation of apoptotic cell death in these cells (unpublished data). Another study showed that PDT induced apoptosis in cancer cells independent on p53 (Almeida et al., 2004).

\subsection{Extrinsic apoptosis pathway}

This pathway is connected with initiation of the apoptotic process in response to induction of a cell surface receptor, such as the tumor-necrosis factor receptor (TNF-R) family of death receptor, or the apoptotic program can be initiated when a death ligand (Fas ligand - FasL) interacts with a cell surface receptor (Fas/APO-1/CD95) (Mupidi 2004). Death receptor mediated apoptosis occurs during photodynamic therapy when photosensitizers preferentially localize in the cell membrane. In human epidermoid carcinoma A431 treated photodynamic reaction with phthalocyanine 4 increasing levels of the surface death receptor Fas and of its ligand FasL were observed. Additionally, in the same conditions caspase- 8 cleavage was increased in Pc4-sensitized A431 cells. The function of the Fas/FasL system in PDT was also observed in canine kidney cells and hamster lung fibroblast after photosensitization with Photofrin (Almeida 2004). PDT-induced apoptosis is dependent on many metabolic signals which have an influence on the apoptotic pathway. Many examinations suggest that both the intrinsic and extrinsic pathway were crosslinked during photosensitization. 


\section{PDT in melanoma treatment}

Results from preclinical and clinical studies conducted worldwide over a 25-year period have established PDT as a useful treatment approach for some cancers (Mitton D, 2005). For more than 20 years scientists have maintained that PDT is not effective for pigmented melanomas (Ambrosone et al., 2005). Scientists focused on the improvement of inefficient PDT due to the competition between the absorbance of melanin from melanoma and the absorbance of photosensitizers at the photosensitizer excitation light wavelength. Melanin absorbs light over the entire wavelength region used for PDT (400-750 nm) (Ma et al., 2007). This was one reason why pigmented melanoma has been excluded in some PDT studies (Lim et al., 2004). It is well known that the longer wavelength of light absorption is, the deeper photosensitizer penetrates the skin (Woodburn et al., 1998). Since establishing the substantial heterogeneity of melanomas and their varying resistance to radio- and phototherapy, there have been intensive studies on the molecular processes occurring in these neoplasms during therapy (Kusmierz et al., 2009).

The limitations of the porphyrin-derived photosensitizers with regard to light penetration into tissues promoted the synthesis of longer wavelength absorbing photosensitizers (Kreimer- Birnbaum, 1989). PDT treatment with lutetium texaphyrin (PCI-0123) (excitation at $732 \mathrm{~nm}$ ) promoted survival of mice bearing the highly pigmented B16F10 melanoma (Woodburn et al., 1998). Also in these studies tumor apoptosis was evident in the PDTtreated neoplasms after irradiation. PDT is a process with membranes being a principal target (Henderson et al., 1992). Woodburn et al. performed a confocal laser scanning microscopy studies with PDT and PCI-0123. Thre was proved that PDT destroys the melanosomal membrane, which leads to death due to oxidative stress of cells (Woodburn et al., 1997 and 1998).

An important aspect of the antitumour effectiveness of PDT is related to the distribution of the photosensitizer. The localization of the drug in cytoplasmic organelles during PDT plays a major role in cell death (Saczko et al., 2007). It was suggested that localization of photosensitizing drugs in the plasma membrane, or in lysosomes, leads to necrosis after PDT treatment. Localization in the mitochondrial membrane causes apoptosis (Chen et al., 2000). Intracellular accumulation of the photosensitizing drug is one of the most important factors to determine the efficacy of PDT (Saczko et al., 2007; Lam et al., 2001; Ogura et al., 2003). Photofrin (Ph) was the first photosensitizer used in PDT of cancer. This drug has proved to be effective in the treatment of many cancers (Almeida et al., 2004). Ph has been involved in several mechanisms in PDT, such as cytotoxicity and apoptosis (Konan et al., 2002). Saczko et al. showed that the intracellular localization of $\mathrm{Ph}$ in a cultured malignant melanoma (Me45) cell line is mainly intracellular compartments and mitochondrial membranes (Saczko et al., 2007). Ricchelli et al. also reported that Ph was localized in the mitochondria in vitro (Ricchelli et al., 1990). Mitochondria play an important role in the early events of apoptosis (Lam et al., 2001; Patito et al., 2001). Marchetti et al. demonstrated that $\mathrm{Ph}$ is a ligand for the mitochondrial peripheral benzodiazepine receptor, which is responsible for triggering pore transition (Saczko et al., 2007, Marchetti et al., 1996).

The mitochondrial apoptotic pathway was also shown by Chen et al. in therapy with methylene blue (MB) (Chen et al., 2008). It is a photosensitizer which has excellent photochemical properties. $\mathrm{MB}$ is well known to have a high quantum yield of intersystem crossing and singlet oxygen generation and can produce radical species in the presence of reducing agents (Gabrielli et al., 2004; Tardivo et al., 2005). This photosensitizing drug has 
affinity for melanocyte-produced melanin, which contributes to selective absorption of this compound by cutaneous melanomas (Link et al., 1989). MB showed enhanced penetration efficiency into melanoma cells and also in mitochondrial membranes, which induced apoptotic cell death by causing mitochondrial dysfunction (Ball et al., 1998). Chen et al. showed that MB-PDT could induce apoptotic cell death through the photochemical generation of reactive oxygen species that activate the caspase- 9 and caspase- 3 apoptosis pathway (Chen et al., 2008). A transplantable mouse melanoma model showed that the tumor size in treated mice decreased, which was associated with enhanced apoptotic cell death.

Nowak-Sliwinska et al. have tested several photosensitizers to evaluate their photoefficiency in the Cloudman S91/I3 mouse melanoma cell line (Nowak-Sliwinska et al., 2006). They compared the efficiency of the photodynamic effect using cyanine (MC540) and porphyrin derivative photosensitizers (Photofrin and verteporfin). Their study showed that verteporfin and Photofrin are effective compounds with the classical type II mechanism of photodynamic reaction, but verteporfin is the most potent photosensitizer against melanoma cells. Generation of singlet molecular oxygen by photo-activated verteporfin was more than twice as high as in the case of Photofrin. The LD50 light dose for verteporfin was four times lower than for Photofrin, in spite of the much lower concentration used ( 2 vs. 10 $\mathrm{lg} / \mathrm{ml}$ ) and 10 times higher for MC540 than for Photofrin. Busetti et al. described the pharmacokinetics of verteporfin in mice and showed that a single treatment inhibited growth of B16 tumor (Busetti et al., 1999).

Induction of apoptosis by PDT seemed to play an important role in the photodynamic treatment efficacy (Barge et al., 2004). Ph-PDT induces cell death in the human Beidegröm Melanoma (BM) cell line mainly through apoptosis (Saczko et al., 2005). The application of comet assay to study the influence of Ph-PDT on BM cells showed that some types of DNA damage depend on photosensitizer concentration, as well as on time and dose of irradiation. Similar results were obtained by Barge et al. (Barge et al., 2004) in human melanoma cells using a new silicon phthalocyanine photosensitizer and by Haddad et al. in murine malignant melanoma in vitro and in vivo using aluminum phthalocyanine (AlpcS4) (Haddad et al., 1998)

Higher doses of light and sensitizer lead to a dose-dependent augmentation of reaction oxygen species in melanoma cells (Kästle et al., 2011; Kolarova et al., 2007). A widely used photosensitizer is the protoporphyrin IX (PpIX) precursor 5-aminolevulinic acid (ALA). ALA is the first molecule in heme biosynthesis which is converted to the active photosensitizer PpIX in the mitochondria. Kästle et al. showed that WM451LU cells are more affected by ALA-PDT than non-tumorigenic keratinocytes (Kästle et al., 2011). The reason for this is elevated porphobilinogen deaminase activity and a significant decrease in ferrochelatase activity in cancer cells (Dailey et al., 1984; Kästle et al., 2011; Leibovici et al., 1988). What is more, PDT of melanoma with porphyrin and porphyrin derivatives is effective and well tolerated by patients (Szurko et al., 2003).

Kolarova et al. studied the effects of zinc-5,10,15,20-tetrakis(4-sulfonatophenyl) porphyrin (ZnTPPS 4 ) on human G361 melanoma cell line (Kolarova et al., 2005). Analysis of DNA damage in the cell line after PDT was proved by comet assay. This treatment method gave rise to DNA damage. Further studies demonstrated that $\mathrm{ZnTPPS}_{4}$ induces the highest ROS production in the G361 cell line compared to other porphyrins - TPPS 4 and PdTPPS 4 . A correlation was observed between ROS production and cell survival. The results 
demonstrate that the photodynamic effect depends on sensitizer type, its concentration and light dose (Kolarova et al., 2007). Later research showed the most significant phototoxic effect of chloraluminium phthalocyanine disulfonate ( $\left.\mathrm{ClAlPcS}_{2}\right)-\mathrm{PDT}$ in spite of significantly higher ROS production induced by ZnTPPS 4 -PDT on G361 cells (Krestyn et al., 2010).

HO-1 has a number of potential protective effects against oxidative stress. Additionally, the last catalytic product of $\mathrm{HO}-1$ is $\mathrm{CO}$. $\mathrm{CO}$ acts as a second messenger. It has antiinflammatory and anti-apoptotic effects (Bilban et al., 2008). Its expression is closely related to the oxidative stress levels in the cells (Saczko et al., 2007). An increase in expression of HO-1 following photodynamic therapy was observed by Gomer et al. (1991) and Nowis et al. (2006). They demonstrated that overexpression of HO-1 protects cancer cells against PDT with Photofrin. Other authors have also reported that PDT with 5-ALA resulted in increased formation of ROS and further enhancement of HO-1 induction (Frank et al., 2007). Kästle et al. applied inhibitors of HO-1 and PARP what improved the efficiency of photodynamic treatment (Kästle et al., 2011). Drastic reduction in viability by the addition of ZnPpIX is among other things the result of higher ROS levels (75\% more than without ZnPpIX) after irradiation and inhibition of HO-I (Kästle et al., 2011). Also inhibition of the protein PARP-1 seems to be a plausible addition to anticancer treatment. PARP is a protein involved in a number of cellular processes. One of its important functions is to assist in the repair of single-strand DNA breaks. If one single-strand broken DNA is reduplicated, a doublestrand broken DNA results. If PARP is inhibited, cell death occurs (D'Amours et al., 1999). In the co-culture $65 \%$ of WM451LU melanoma cells and 35\% of HaCaT keratinocytes were present before PDT. After PDT the proportion was $41 \%$ of melanoma cells and $59 \%$ of HaCaT cells. Combination of both inhibitors with PDT improves these results to $16 \%$ of melanoma cells and $84 \%$ of HaCaT cells. Addition of HO-1 and PARP inhibitors significantly improves the efficiency of photodynamic treatment (Kästle et al., 2011).

A very interesting study was presented by $\mathrm{Ma}$ et al. (2007). In that work reflectance spectroscopy was applied to study depigmentation of human and murine skin with different melanin contents, and effects induced by PDT with topical application of methyl 5aminolevulinate (MAL) on B16F10 melanotic melanomas transplanted to mice. Skin depigmentation leads to increase in reflectance. PDT with violet light $(420 \mathrm{~nm})$ bleached some of the melanin in the skin above the B16F10 melanomas. It was concluded that violet light in PDT can bleach melanin in melanotic tumors and therefore increase their sensitivity to red light $(634 \mathrm{~nm})$. This finding indicates a new PDT modality (Ma et al., 2007).

The direct effects of PDT are cytotoxic for cancer cells, but it also could induce an immune system response, what has been proved in vitro (Blom et al., 1997). Treatment of ocular melanoma cells with hematoporphyrin ester (HPE)-PDT temporally alters the expression of HLA class I and $\beta 2$-microglobulin. This may affect anti-tumor-immune responses.

\section{Conclusions}

Photodynamic therapy, a minimally invasive therapeutic modality, has been shown to be effective in a number of oncological and non-oncological conditions. The advantages of PDT application are better cosmetic outcomes without surgical scars or the discoloration that is evident in surgery or cryotherapy. Moreover, PDT may be used to decrease the size of a large tumor, which can be subsequently removed with a smaller excision. The experience in the use of PDT in the treatment of other skin diseases, including psoriasis, sarcoidosis, acne and human papillomavirus infections, is preliminary and undergoing clinical testing. 
Although the idea of PDT usage is rather simple, the procedure is complicated by several parameters such as the formulation of the photosensitizing agents, the mode of delivery and duration of application, as well as the multiple light-specific parameters, such as exact wavelength, duration and intensity of various light sources. With the application of secondgeneration, stable, lipophilic photosensitizers with optimized wavelengths, PDT may be a promising tool for therapy in skin cancer. Melanoma is the most severe of all skin neoplasms as it may grow rapidly and metastasize. For many years melanoma, mainly due to the presence of melanotic biopolymers and the presence of gene mutations which code proapoptotic proteins, has been included in the group of resistant irradiation cancers. However, the research in recent years has indicated high variation in sensitivity in melanoma cells. This information has led many researchers to focus on examining the potential use of photodynamic therapy (PDT) in the fight against this cancer. The application of photodynamic therapy opens new perspectives in treatment of this tumor. Photodynamic therapy is an effective local cancer treatment that induces cytotoxicity through intercellular generation of reactive oxygen species. There are three indispensable components in this therapy: a photosensitizer, light, and oxygen inside the diseased tissue. The photosensitizer is accumulated in the target cells and absorbs light of certain wavelength. The energy is transferred to oxygen and highly reactive oxygen species are generated. This is usually singlet oxygen. Potential cellular targets for photodynamic therapy are the cell membrane and membranous organelles such as mitochondria, lysosome and nuclei. The disintegration of cellular structures and modulation of genetic information induced by PDT leads cancer cells to a death pathway. Numerous studies suggest that the exposure of tumor cells to PDT can lead to cell death via two separate processes: apoptosis and necrosis. In contrast to necrosis, apoptosis is an energy-dependent, distinct form of cell death that follows a sequence of genetically programmed events and proceeds without inflammation. Morover there was also noticed that photodynamic therapy can increase the radical and the oxidant processes in oncological patients whose antioxidative mechanisms are overworked.

Potential targets for PDT in melanoma eradication include cell proliferation inhibition, activation of cell death, reduction in pro-survival autophagy and a decrease in the cellular melanocytic antioxidant system. As we have indicated, more research on PDT with melanoma is needed to determine the exact parameters optimal for the treatment of this disease. In our opinion PDT should be considered as a good candidate for treatment in malignant melanoma. This technique may be also a promising device for melanoma in combation with standard therapies.

\section{Acknowledgment}

This work was supported by a grant of the Ministry of Science and Higher Education, Poland, grant No. 5409/B/P01/2011/40 (A. Gamian).

\section{References}

Aliya, S.; Reddanna, P.; \& Thyagaraju, K. (2003). Does glutathione S-transferase Pi (GST-Pi) a marker protein for cancer? Molecular and Cellular Biochemistry, Vol.253, No.1-2, pp. 319-27, ISSN 0300-8177 
Allison, R.R.; Sibata, C.H. (2010) Oncologic photodynamic therapy photosensitizers: A clinical review. Photodiagnosis and Photodynamic Therapy, Vol.7, No.2 (April 2010), pp. 61-75, ISSN 1873-159

Almeida, R.D.; Manadas, B.J.; Carvalho, A.P.; Duarte, C.B. (2004). Intracellular signalling mechanism in photodynamic therapy. Biochimica et Biophysica Acta, Vol.1704, No.2 (June 2004), pp. 59-86, ISSN 0006-3002

Ambrosone, C.B.; Ahn, J.; Singh, K.K.; Rezaishiraz, H.; Furberg, H.; Sweeney, C.; Coles, B.; Trovato, A. (2005). Polymorphisms in Genes Related to Oxidative Stress (MPO, MnSOD, CAT) and Survival After Treatment for Breast Cancer. Cancer Research, Vol.65, No.3 (February 2005), pp. 1105-1111, ISSN 0008-5472

Bailey, M.S.; Landar, A.; \& Darley-Usmar, V. (2005). Mitochondrial proteomics in free radical research. Free Radical in Biology and Medicine, Vol.38, No.2, pp. 175-188, ISSN 0891-5849

Ball, D.J.; Luo, Y.; Kessel, D.; Griffiths, J.; Brown, S.B. \& Vernon, D.I. (1998). The induction of apoptosis by a positively charged methylene blue derivative. Journal of Photochemistry and Photobiology. B, Biology, Vol.42, No.2 (April 1998), pp. 159-63, ISSN 1011-1344

Bar, K.B.; Saczko, J.; Ziółkowski, P.; Chwiłkowska, A.; Słomska, I.; Drąg-Zalesińska, M.; Wysocka, T.; Duś, D. (2007). Photofrin II based photosensitization of human ovarian clear-cell carcinoma cell Line (OvBH-1). Pharmacological Reports, Vol.59, suppl.1, ISSN 1734-1140

Barge, J.; Decreau, R.; Julliard, M.; Hubaud, J.C.; Sabatier, A.S.; Grob, J.J.; Verrando, P. (2004). Killing efficacy of a new silicon phtalocyanine in human melanoma cells treated with photodynamic therapy by early activation of mitochondrion-mediated apoptosis. Experimental Dermatology, Vol.13, No.1 (January 2004), pp. 33-44, ISSN 0906-6705

Bartosz, G. (2003). Druga twarz tlenu, Wolne rodniki w przyrodzie, PWN, Warszawa

Bilban, M.; Haschemi, A.; Weigel, B.; Chin, B.Y.; Wagner, O.; Otterbein, L.E. (2008). Heme oxygenase and carbon monoxide initiate homeostatic signalling. Journal of Molecular Medicine, Vol.86, No.3 (October 2007), pp. 267-279, ISSN 0946-2716

Bizik, J.; Kankuri, E.; Ristimaki, A.; Taieb, A.; Vapaatalo, H.; Lubitz, W.; Waheri, A. (2004). Cell-cell contracts trigger programmed necrosis and induce cyclooxygenase-2 expression. Cell Death and Differentiation, Vol.11, No.4 (October 2003), pp. 183-95

Blom, D.J.; Schuitmaker, H.J.; de Waard-Siebinga, I.; Dubbelman, T.M.; Jager, M.J. (1997). Decreased expression of HLA class I on ocular melanoma cells following in vitro photodynamic therapy. Cancer Letters, Vol.112, No. 2 (January 1997), pp. 239-43, ISSN 0304-3835

Buggiani, G.; Trojano, R.; Rossi, R.; Lotti, T. (2008). Photodynamic therapy: off-label and alternative use in dermatological practice. Photodiagnostic $\mathcal{E}$ Photodynamic Therapy, Vol.1, pp. 1-5

Bunz, F.; Hwang, P.M.; Torrance, C..; Waldman, T.; Zhang, Y.; Dillehay, L.; Wiliams, J.; Lengauer, C.; Kinzler, W.; Vogelstein, B. (1999). Disruption of p53 in human cancer cells alters the responses to therapeutic agents. Journal of Clinical Investigation, Vol.104, No.3 (August 1999), pp. 263-269, ISSN 0021-9738

Busetti, A.; Soncin, M.; Jori, G.; Rodgers, M.A.J. (1999). High efficiency of benzoporphyrin derivative in the photodynamic therapy of pigmented malignant melanoma, British Journal of Cancer, Vol.79, No.5/6, pp. 821-824, ISSN 0007-0920 
Buytaret, E.; Callewaert, G.; Hendrickx, N.; Scorrano, L.; Hartman, D.; Mssiaen, L.; Vandenheede, J.R.; Heirman, I.; Grotten, J.; \& Agostinis, P. (2006) Role of endoplasmic reticulum depletion and multidomain proapoptotic BAX and BAK proteins in shaping cell death after hypericin-mediated photodynamic therapy. The FASEB Journal; 20: 756-758, ISSN: 0892-6638

Capella M. A. M., Capella, L. S. (2003) A light in multidrug resistance: photodynamic treatment of multidrug-resistant tumors, Journal of Biomedical Science; Vol. 10, No.4, pp: 361-366, ISSN 1021-7770

Castano, A.P.; Demidova, T.N.; Hamblin, M.R. (2004). Mechanisms in photodynamic therapy: Part two - photosensitizers, photochemistry and cellular localization. Photodiagnosis and Photodynamic Therapy, Vol.1, pp. 279-293, ISSN 1572-1000

Chen, J.Y.; Heung N.K.; Fung, M.C.; Wen, J.M.; Leung, W.N.; Mak, N.K. (2000). Subcellular localization of Merocyanine 540 (MC540) and induction of apoptosis in murine myeloid leukemia cells, Photochemistry and Photobiology, Vol.72, No.1 (May 2007), pp. 114-120, ISSN 0031-8655

Chen, Y.; Zheng, W.; Li, Y.; Zhong, J.; Ji, J.; Shen, P. (2008). Apoptosis induced by methyleneblue-mediated photodynamic therapy in melanomas and the involvement of mitochondrial dysfunction revealed by proteomics. Cancer Science, Vol.99, No.10 (October 2008), pp. 2019-2027,

Chiu, S.M.; Xue, L.Y.; Usada, J.; Azizuddin, K. \& Oleinick, N.L. (2003). Bax is essential for mitochondrion-mediated apoptosis but not for cell death caused by photodynamic therapy. British Journal of Cancer, Vol.89, No.8 (October 2003), pp. 1590-1597, ISSN 0007-0920

Chow, C.K.; Ibrahim, W.; Wei, Z.; \& Chan, A.C. (1999) Vitamin E regulates mitochondrial hydrogen peroxide generation. Free Radical in Biology and Medicine, Vol.27, No.5-6, pp. 580-587, ISSN 0891-5849

Chwiłkowska, A.; Saczko, J.; Kulbacka, J.; Ługowski, M.; Drąg-Zalesińska, M.; Wysocka, T.; Banaś, T. (2006). Influence of photofrin on survival and apoptosis of the Jurkat leukemic T-cell line undergoing photodynamic therapy. Advances in Clinical and Experimental Medicine, Vol.15, No.6, pp. 999-1002, ISSN 1230-025X

Dahle, J.; Steen, H.B.; Moan, J. (1999). The mode of cell death induced by photodynamic treatment depends on cell density. Photochemistry and Photobiology, Vol.70, No.3 (January 2008), pp. 363-367, ISSN 0031-8655

Dailey, H.A.; Smith, A. (1984). Differential interaction of porphyrins used in photoradiation therapy with ferrochelatase. Biochemical Journal, Vol.223, No.2, pp. 441-445, ISSN 0264-6021

D'Amours, D.; Desnoyers, S.; D'Silva, I.; Poirier, G.G. (1999). Poly(ADP-ribosylation) reaction in the regulation of nuclear functions. Biochemical Journal, Vol.342, No.2 (September 1999), pp. 249-268, ISSN 0264-6021

De Rosa, F.S.; Bently, M.V.L.B. (2000). Photodynamic therapy of skin cancers: sensitizers, clinical studies, and future directives. Pharmaceutical Research, Vol.17, No.12, pp. 1447-1455, ISSN 0724-8741

Dellinger, M. (1996). Apoptosis or necrosis following Photofrin photosensitization: Influence of the incubation protocol. Photochemistry and Photobiology, Vol.64, No.l, pp. 182-187, ISSN 0031-8655

Dulak, J.; \& Jozkowicz, A. (2003). Carbon monoxide - a "new" gaseous modulator of gene expression. Acta Biochimica Polonica, Vol.50, No.1, pp. 31-47, ISSN 0001-527X 
Edinger, A.L.; \& Thompson, C.B. (2004). Death by design: apoptosis, necrosis and autophagy. Current Opinion in Cell Biology, Vol.16, No.6, pp. 663-669, ISSN 09550674

El-Deiry, W.S. (1998). Regulation of p53 downstream genes. Seminars in Cancer Biology. Vol.8, No.5, pp. 345-357, ISSN 1044-579X

Fabris, C.; Valduga, G.; Miotto, G.; Borsetto, L.; Jori, G.; Garbisa, S. \& Reddi, E. (2001). Photosensitization with Zinc (II) Phthalocyanine as a switch in the decision between apoptosis and necrosis. Cancer Research, Vol.61 (October 2001), pp. 74957500, ISSN 0008-5472

Fiers, W.; Beyaert, R.; Declercq, W.; Vandenabeele, P. (1999). More than one way to die: apoptosis, necrosis and reactive oxygen damage. Oncogene, Vol.18, No.54 (December 1999), pp. 7719-7730, ISSN 0950-9232

Fisher, A.M.; Rucker, N.; Wong, S.; Gomer, C.J. (1998). Differential photosensitivity in wild type and mutant p53 human colon carcinoma cell lines. Journal of Photochemistry and Photobiology. B, Biology, Vol.42, No.2 (June 2005), pp. 104-107

Fisher, A.M.; Danenberg, K.; Benerjee, D.; Bertino, J.; Danenberg, P.; Gomer, CJ. (1997). Increased photosensitivity in HL60 cells expressing wild type p53. Photochemistry and Photobiology, Vol.66, No.2 (January 2008), pp. 265-270, ISSN 0031-8655

Fisher, A.M.R.; Murphree, A.L.; Gomer, C.J. (1995) Clinical and preclinical photodynamic therapy. Lasers in Surgery and Medicine, Vol.17, No.1, pp. 2-31, ISSN 0196-8092

Frank, J.; Lornejad-Schäfer, M. R.; Schöffel, H. (2007). Inhibition of heme oxygenase-1 increases responsiveness of melanoma cells to ALA-based photodynamic therapy. International Journal of Oncology, Vol.31. No.6 (January 2008), pp. 1539-1545, ISSN 1019-6439

Gabrielli, D.; Belisle, E.; Severino, D.; Kowaltowski, A.J.; Baptista, M.S. (2004). Binding, aggregation and photochemical properties of methylene blue in mitochondrial suspensions. Photochemistry and Photobiology, Vol.79, No.3 (May 2007), pp. 227-32, ISSN 0031-8655

Gałecka, E.; Mrowicka, M.; Malinowksa, K. et al.: (2008). Wybrane substancje nieenzymatyczne uczestniczące $\mathrm{w}$ procesie obrony przed nadmiernym wytwarzaniem wolnych rodników. Polski Merkuriusz Lekarski, Vol.147, No.25, pp. 269-272, ISSN 1426-9686

Golstein, P.; \& Kroamer, G. (2005). Redundant cell death mechanisms as relics and backups. Cell Death and Differentiation, Vol.2, pp. 1490-1496, ISSN 1350-9047

Golstein, P. \& Kroemer, G. (2006). Cell death by necrosis: towards a molecular definition. Trends in Biochemical Sciences, Vol.32, No.1, pp. 37-43, ISSN 0167-7640

Gomer, C.J.; Luna M.; Ferrario, A.; \& Rucker, N. (1991). Increased transcription and translation of heme oxygenase in Chinese hamster fibroblasts following photodynamic stress or Photofrin II incubation. Photochemistry and Photobiology, Vol.53, No.2, pp. 275-279, ISSN 0031-8655

Granville, D.J.; McManus, B.M.; Hunt, D.W. (2001) Photodynamic therapy: shedding light on the biochemical pathways regulating porphyrin-mediated cell death. Histology and Histopathology, Vol.16, No. 1 (January 2001), pp. 309-17, ISSN 0213-3911

Grebenova, D.; Kuzelova, K.; Smetana, K. (2003). Mitochondrial and endoplasmic reticulum stress-induced apoptotic pathways are activated by 5-aminolevulinic acid-based photodynamic therapy in HL60 leukemia cells. Journal of Photochemistry and Photobiology B: Biology, Vol.69, No.2, pp. 71-85 
Haddad, R.; Blumenfeld, A.; Siegal, A.; Kaplan, O.; Cohen, M.; Skornick, Y.; Kashtan, H. (1998). In vitro and in vivo effects of photodynamic therapy on murine malignant melanoma. Annals of Surgical Oncology, Vol.5, No.3, pp. 241-247, ISSN 1068-9265

Halliwell, B. (2000) A super way to kill cancer cells. Nature Medicine, 6(10): 1105-1106, ISSN: 1078-8956

Haylett, A.K.; Ward, T.H.; \& Moore, J.V. (2003). DNA damage and repair in Gorlin syndrome and normal fibroblasts after aminolevulinic acid photodynamic therapy: a comet assay study. Photochemistry and Photobiology, Vol.78, No.4, pp. 337-341, ISSN 0031-8655

Henderson, B.W.; Doughtery, T.J. (1992) How does photodynamic therapy work? Photochemistry and Photobiology, Vol.55, No.1 (January 1992), pp. 145-157, ISSN 00318655

Hightower, L.E.; \& Hendershot, L.M. (1997). Molecular chaperones and the heat shock response at Cold Spring Harbor. Cell Stress and Chaperones, Vol.2, No.1, pp. 1-11, ISSN 1355-8145

Hsieh, Y.J.; Wu, C.C.; Chang, H.C.; \& Yu J.S. (2003). Subcellular localization of photofrin determines the death phenotype of human epidermoid carcinoma A431 cells triggered by photodynamic therapy: when plasma membranes are the main targets. Journal of Cellular Physiology, Vol.194, No.3, pp. 363-375, ISSN 0021-9541

Huang, P., Feng, L.I., Oldham, A., Keating, M.J., Plunkett, W. (2000) Superoxide dismutase as a target for the selective killing of cancer cells. Nature, 407: 390-395, ISSN: 00280836

Juzeniene, A.; Moan, J. (2007). The history of PDT in Norway. Part one - identification of basic mechanisms of general PDT. Photodiagnosis and Photodynamic Therapy, Vol.4, No.1, pp. 3-11, ISSN 1572-1000

Kästle, M.; Grimm, S.; Nagel, R.; Breusing, N.; Grune, T. (2010). Combination of PDT and inhibitor treatment affects melanoma cells and spares keratinocytes. Free Radicals in Biology and Medicine, Vol.50, No.2 (January 2011), pp. 305-312, ISSN 0891-5849

Kawczyk-Krupka, A. et al. (2001). Terapia fotodynamiczna i jej znaczenie immunomodulujące w leczeniu chorób skóry i leukoplakii jamy ustnej. Acta BioOptica et Informatica Medica. Inżynieria Biomedyczna, Vol. 7, pp. 67-72, ISSN 1234-5563

Kelekar, A.\& Thompson, C.B. (1998). Bcl-2 family proteins: the role of the BH3 domain in apoptosis. Trends in Cell Biology, Vol.8, No.8 (October 2998), pp. 324-330

Kessel, D. \& Arroyo, A.S. (2007). Apoptotic and autophagic responses to Bcl-2 inhibition and photodamage. Photochemical \& Photobiological Sciences, Vol.6, No.12 (July 2007), pp. 1290-1295

Kessel, D. \& Luo, Y. (1998). Mitochondrial photodamage and PDT-induced apoptosis. Journal of Photochemistry and Photobiology B: Biology, Vol.42, No.2 (April 1998), pp. 89-95

Kessel, D.; Luo, Y.; Deng, Y.; \& Chang, C.K. (1997). The role of subcellular localization in initiation of apoptosis by photodynamic therapy. Photochemistry and Photobiology, Vol.65, No.3, pp.422-426, ISSN 0031-8655

Kessel, D.; Luo, Y.; Deng, Y.; Cheng, C.K. (1997). The role of subcellular localization in initiation of apoptosis by photodynamic therapy. Photochemistry and Photobiology, Vol.65, No.3 (March 1997), pp. 422-426, ISSN 0031-8655 
Kessel, D.; Poretz, R.D. (2000). Sites of photodamage induced by photodynamic therapy with a chlorine e6 triacetoxymethyl ester (CAME). Photochemistry and Photobiology, Vol.71, No.1 (May 2007), pp. 94-6, ISSN 0031-8655

Ketabachi, A..; Macrobert, A.; Speight, P.M.; Benn, J.H. (1998). Induction of apoptotic cell death by photodynamic therapy in human keratinocytes. Archives of Oral Biology, Vol.43, No.2 (February 2008), pp. 143-149, ISSN 0003-9969

Khan, M.A.; Tania, M.; Zhang, D.; \& Chen, H. (2010). Antioxidant enzymes and cancer. Chinese Journal of Cancer Research, Vol.22, No.2, pp. 87-92, ISSN 1000-9604

Kiesslich, T.; Plaetzer, K.; Oberdanner, C.B.; Berlanda, J.; Obermair, F.J.; \& Krammer, B. (2005) Differential effects of glucose deprivation on the cellular sensitivity towards photodynamic treatment-based production of reactive oxygen species and apoptosis induction. The FEBS Letters, Vol. 579, No. 1 (3 January 2005), pp 185-190, ISSN 0014-5793

Kolarova, H.; Bajgar, R.; Tomankova, K.; Nevrelova, P.; Mosinger, J. (2007). Comparison of sensitizers by detecting reactive oxygen species after photodynamic reaction in vitro. Toxicology in Vitro, Vol.21, No.7,(May 2007), pp. 1287-1291

Kolarova, H.; Macecek, J.; Nevrelova, P.; Huf, M.; Tomecka, M.; Bajgar, R.; Mosinger, J.; Strnad, M. (2005). Photodynamic therapy with zinc-tetra(p-sulfophenyl)porphyrin bound to cyclodextrin induces single strand breaks of cellular DNA in G361 melanoma cells. Toxicology in Vitro, Vol.19, No.7 (August 2005 ), pp. 971-974

Konan, Y.N.; Gurny, R.; Allemann, E. (2002) State of the art in the delivery of photosensitizers for photodynamic therapy. Journal of Photochemistry and Photobiology, Vol.66, No.2 (December 2001), pp. 89-106, ISSN 1011-1344

Krestyn, E.; Kolarova, H.; Bajgar, R.; Tomankova, K. (2010). Photodynamic properties of ZnTPPS4, ClAlPcS2 and ALA in human melanoma G361 cells. Toxicology in Vitro, Vol.24, No.1 (August 2009), pp. 286-91

Kroemer, G. (2005). Classification of cell death: recommendations of the nomenclature committee on cell death. Cell Death and Differentiation, Vol.12, No.2, pp. 14631467, ISSN 1350-9047

Kroemer, G.; \& Martin, S.J. (2005). Caspase independent cell death. Nature Medicine, Vol.11, No.7, pp. 725-730, ISSN 1078-8956

Kroemer, G.; Dallaporta, B.; \& Resche-Rigon, M. (1998). The mitochondrial death/life regulator in apoptosis and necrosis. Annual Review of Physiology, Vol.60, pp. 619642, ISSN 0066-4278

Kroemer, G.; Galluzzi, L.; \& Brenner, C. (2007). Mitochondrial membrane permeabilization in cell death. Physiological Reviews, Vol.87, No.1, pp. 99-163, ISSN 0031-9333

Kulbacka, J.; Chwiłkowska, A.; Bar, J.; Poła, A.; Banaś, T.; Gamian, A.; \& Saczko, J. (2010). Oxidative alterations induced in vitro by the photodynamic reaction in doxorubicin-sensitive (LoVo) and -resistant (LoVoDX) colon adenocarcinoma cells. Experimental Biology and Medicine, Vol.235, No.1, pp. 98-110, ISSN 1535-3699

Kurl, S.; Tuomainen, T.P.; Laukkanen, J.A.; Nyyssönen, K.; Lakka, T.; Sivenius, J.; \& Salonen, J.T. (2002). Plasma vitamin $C$ modifies the association between hypertension and risk of stroke. Stroke, Vol.33, No.6, pp. 1568-1573, ISSN 0039-2499

Kuroda, M., Himei, K., St. Clair, D. K., Urano, M., Yoshino, T., Akagi, T., Asaumi, J., Akaki, S., Takeda, Y., Kanazawa, S., and Hiraki, Y. (2000) Overexpression of manganese superoxide dismutase gene suppresses spontaneous apoptosis without a resultant 
alteration in in vivo growth of the mouse fibrosarcoma, FSa-II. Anticancer Research, 20, 7-10, ISSN : 0250-7005

Kusmierz, D.; Latocha, M.; Zielińska, A.; Nawrocka-Musial, D.; Sliupkas-Dyrda E. (2009). The expression of the melanogenesis pathway genes TYR, TYRP-1, and TYRP-2 and the synthesis of melanin in SH-4 melanoma cells after photodynamic therapy with photolon. (2009). Advances in Clinical and Experimental Medicine. Vol.18, No.5 (September 2009), pp. 449-459, ISSN 1230-025X

Łagowska-Lenard, M.; Bielewicz, J.; Raszewski, G. et al. (2008). Stres oksydacyjny w udarze mózgu. Polski Merkuriusz Lekarski, Vol.147, No.25, pp. 205-208, ISSN 1426-9686

Lam, M.; Oleinick, N.L.; Nieminien, A.L. (2001). Photodynamic therapy-induced apoptosis in epidermoid carcinoma cells: reactive oxygen species and mitochondrial inner membrane permeabilization. Journal of Biological Chemistry, Vol.276, No.50 (September 2001), pp. 47379-47386, ISSN 0021-9258

Lavie, G.; Kaplinsky, C.; Toren, A.; Aizman, I.; Meruelo, D.; Mazur, Y.; Mandel, M. (1999). A photodynamic pathway to apoptosis and necrosis induced by dimethyl tetrahydroxyhelianthrone and hypericin in leukaemic cells: possible relevance to photodynamic therapy. British Journal of Cancer, Vol. 79, No.3-4, 1pp. 423-32, ISSN 0007-0920

L'Ecuyer, T; Allebban, Z; Thomas, R; Vander Heide, R. Glutathione S-transferase overexpression protects against anthracycline-induced H9C2 cell death, American Journal of Physiology, Heart Circulatory Physiology, 2004; 286(6): 2057-2064, ISSN: 0363-6135

Leibovici, L.; Schoenfeld, N.; Yehoshua, H. A.; Mamet, R.; Rakowsky. E.; Shindel, A.; Atsmon, A. (1988). Activity of porphobilinogen deaminase in peripheral blood mononuclear cells of patients with metastatic cancer. Cancer, Vol.62, No.11 (June 2006), pp. 2297-2300, ISSN 0008-543X

Leist, M.; Jaattela, M. (2001). Triggering of apoptosis by cathepsins. Cell Death and Differentiation, Vol.8, No.4 (April 2001), pp. 324-326

Lim, D.S.; Ko, S.H.; Lee, W.Y. (2004). Silkworm-pheophorbide a mediated photodynamic therapy against B16F10 pigmented melanoma. Journal of Photochemistry and Photobiology B: Biology, Vol.74 (November 2003) pp. 1-6

Link, E.M.; Brown, I.; Carpenter, R.N.; Mitchell, J.S. (1989). Uptake and therapeutic effectiveness of 125I- and 211At-methylene blue for pigmented melanoma in an animal model system. Cancer Research, Vol.49, No.15, pp. 4332-4337, ISSN 10009604

Lowe, S.W.; Bodis, S.; McClatchey, A.; Remington, L.; Ruley, H.E.; Fisher, D.E.; Housman, D.E.; Jacks, T. (1994). P53 status and efficiency of cancer therapy in vivo. Science, Vol.266, No.5186 (November 1994), pp. 807-810, ISSN 0036-8075

Lukšienè, Ž. (2003) Photodynamic therapy: mechanism of action and ways to improve the efficiency of treatment. Medicina (Kaunas), Vol.39, No.12 (August 2003), pp. 11371150, ISSN 1010-660X

Luo, Y.; Chang, C.K. \& Kessel, D. (1996). Rapid initiation of apoptosis by photodynamic therapy. Photochemistry and Photobiology, Vol.63, No.4 (January 2008), pp. 528-534, ISSN 0031-8655

Ma, L.W.; Nielsen, K.P.; Iani, V.; Moan, J. (2007). A new method for photodynamic therapy of melanotic melanoma - effects of depigmentation with violet light photodynamic 
therapy. Journal of Environmental Pathology, Toxicology and Oncology, Vol.26, No.3, pp. 165-72, ISSN 0731-8898

Majno, G.; \& Joris, I. (1995). Apoptosis, oncosis and necrosis. An overview of cell death. American Journal of Pathology, Vol.146, No.1, pp. 3-15, ISSN 0002-9440

Marchal, S.; Bezdetnaya, L.\& Guillemin, F. (2004). Modality of cell death induced by Foscan ${ }^{\circledR}$-based photodynamic treatment in human colon adenocarcinoma cell line HT29. Biochemistry (Moscow), Vol.69, No.1, pp. 45-49, ISSN 0006-2979

Marchetti, P.; Hirsch, T.; Zamzami, N.; Castedo, M.; Decaudin, D.; Susin, S.A.; Masse, B.; Kroemer, G. (1996). Mitochondrial permeability transition triggers lymphocyte apoptosis. Journal of Immunology, Vol.157, No.11 (December 1996), pp. 4830-4836, ISSN 0022-1767

Mazur, E.; Stołtny, D.; Kwiatek, S.; Kawczyk-Krupka, A.; Latos, W.; \& Sieroń, A. (2010). Diagnostyka (PDD) i terapia fotodynamiczna (PDT) - wskazania i wykorzystanie PDD i PDT w leczeniu uzdrowiskowym. Acta Balneologica, LII, Vol.2, pp.107-111

McCord, J.M. (2002). Superoxide dismutase in aging and disease: an overview. Methods in Enzymology, Vol.349, pp. 331-341, ISSN 0076-6879

McNair, F.I.; Marples, B.; West, C.M.; \& Moore, J.V. (1997). A comet assay of DNA damage and repair in K562 cells after photodynamic therapy using haematoporphyrin derivative, methylene blue and meso-tetrahydroxyphenylchlorin. British Journal of Cancer, Vol.75; No.12, pp. 1721-1729, ISSN 0007-0920

Miller, J.D.; Baron, E.D.; Scull, H.; Hsia, A.; Berlin, J.C.; McCormick, T.; Colussi, V.; Kenny, M.E.; Cooper, K.D.; \& Oleinick, N.L. (2007). Photodynamic therapy with the phthalocyanine photosensitizer Pc4: the case experience with preclinical mechanistic and early clinical-translational studies. Toxicology and Applied Pharmacology, Vol.244, No.3, pp. 290-299, ISSN 0041-008X

Mitsunga, M.; Tsubota, A.; Nariai, K.; Sumi, M.; Yoshikawa, T. (2007). Early apoptosis and cell death induced by ATX-S10Na(II)-mediated photodynamic therapy are Bax- and p53 dependent in human colon cancer cells. World Journal of Gastroenterology, Vol.13, No.5 (February 2007), pp. 692-698

Mitton, D.; Ackroyd, R. (2005). History of photodynamic therapy in Great Britain. Photodiagnosis and Photodynamic Therapy, Vol.2, No.4 (December 2005), pp. 239-246

Mori, M.; Kuroda, T.; Obana, A.; Sakata, I.; Hirano, T.; Nakajima, S.; Hikida, M.; Kumagai, T. (2000). In vitro plasma protein binding and cellular uptake of ATX-S10(Na), a hydrophilic chlorin photosensitizer. Japanese Journal of Cancer Research, Vol.91, No.8, pp. 845-852, ISSN 0910-5050

Morimoto, R.I. (1993). Cells in stress: transcriptional activation of heat shock genes. Science, Vol.259, No.5100, pp. 1409-1410, ISSN 0036-8075

Mupidi, J.R.; Tschopp, J. \& Siegel, RM. (2004). Life and death decisions: secondary complexes and lipid rafts in TNF-receptor family signal transduction. Immunity, Vol.21, No.4 (October 2004), pp. 461-465, ISSN 1074-7613

Nagata, S.; Obana, A.; Gohto, Y.; Nakajima, S. (2003). Necrotic and apoptotic cell death of human malignant melanoma cells following photodynamic therapy using an amphiphilic photosensitizer, ATX-S10(Na). Lasers in Surgery and Medicine, Vol.33, No.1, pp. 64-70, ISSN 0196-8092

Nakajima, S.; Sakata, I.; Takemura, T.; Maeda, T.; Hayashi, H.; Kubo, Y. (1992). Tumor localizing and photosensitization of photochlorin ATX-S10. In : Photodynamic 
Therapy and Biomedical Lasers, S. Spinelli, D. Fante, R. Marchesanin (Ed.), 531-534, Elsevier Science, Amsterdam

Nowak-Sliwinska, P.; Karocki, A.; Elas, M.; Pawlak, A.; Stochel, G.; Urbanska, K. (2006). Verteporfin, Photofrin II and merocyanine 540 as PDT photosensitizers against melanoma cells. Biochemical and Biophysical Research Communications, Vol.349, No.2 (August 2006), pp. 549-555, ISSN 0006-291X

Nowis, D.; Legat, M.; Grzela, T.; Niderla, J.; Wilczek, E.; Wilczynski, G.M.; Glodkowska, E.; Mrowka, P.; Issat, T.; Dulak, J.; Jozkowicz, A.; Was, H.; Adamek, M.; Wrzosek, A.; Nazarewski, S.; Makowski, M.; Stoklosa, T.; Jakobisiak, M.; Golab, J. (2006). Heme oxygenase-1 protects tumor cells against photodynamic therapy-mediated cytotoxicity. Oncogene, Vol. 25, No.24 (February 2006), pp. 3365-3374, ISSN 09509232

Nowis, D.; Makowski, M.; Stokłosa, T.; Legat, M.; Issat, T.; \& Gołąb, J. (2005). Direct tumor damage of photodynamic therapy. Acta Biochimica Polonica, Vol.52, No.2, pp. 339352, ISSN 0001-527X

Ochsner, M. (1997) Photophysical and photobiological processes in the photodynamic therapy of tumours. Journal of Photochemistry \& Photobiology, B: Biology, 1997, 39: 1-18, ISSN1011-1344

Ogura, M.; Sato, S.; Terakawa, M.; Wakisaka, H.; Uenoyama, M.; Ikeda, T.; Ashida, H.; Obara, M. (2003) Delivery of photosensitizer to cells by the stress wave induced by a single nanosecond laser pulse. Japanese Journal of Applied Physics, Vol.42, No.8A (August 2003), pp. 977- 979

Patito, I.A.; Rothman, C.H.; Malik, Z. (2001). Nuclear transport of photosensitizers during photosensitization and oxidative stress. Biology of the Cell, Vol.93, No.5 (November 2001), pp. 285-291, ISSN 0248-4900

Pazos, M.D.C.; \& Nader, H.B. (2007). Effect of photodynamic therapy on the extracellular matrix and associated components. Brazilian Journal of Medical and Biological Research, Vol.40, No.8, pp. 1025-1035, ISSN 0100-879X

Peng, Q.; Moan, J.; Nesland, J.M. (1996). Correlation of subcellular and intratumoral photosensitizer localization with ultrastructural features after photodynamic therapy. Ultrastructural Pathology, Vol.20, No. 2 (March-April 1996), pp. 109-129, ISSN 0191-3123

Pervaiz, S.; Seyed, M.A.; Hirpara, J.L.; Clement, M.V.; Loh, K.W. (1999). Purified photoproducts of merocyanine 540 trigger cytochrome $\mathrm{c}$ release and caspase 8 dependent apoptosis in human leukemia and melanoma cells. Blood, Vol. 93, No.12 (June 1999), pp. 4096-4108, ISSN 0006-4971

Plaetzer, K.; Kiesslich, T.; Verwanger, T.; Krammer, B. (2003). The modes of cell death induced by PDT: an overview, Medical Laser Application, 2003, 18: 7-19, ISSN: 16151615

Plaetzer, K.; Krammer, B.; Berlanda, J.; Berr, F.; Kiesslich, T. (2008). Photophysics and photochemistry of photodynamic therapy: fundamental aspects. Lasers in Medical Science, Vol.24, No.2, pp. 259-268, ISSN 0268-8921

Pockley, A.G. (2003). Heat shock proteins as regulators of the immune response. Lancet, Vol.362, No.9382, pp. 469-476, ISSN 0140-6736

Rahman, K. (2007). Studies on free radicals, antioxidants, and co-factors. Clinical Interventions in Aging, Vol.2, No.2, pp. 219-236, ISSN 1176-9092 
Rastogi, R.P.; Richa, \& Sinha, R.P. (2009). Apoptosis: molecular mechanisms and pathogenicity. EXLI Journal, Vol.8, pp. 155-181, ISSN 1611-2156

Reiners, J.J.Jr.; Caruso, J.A.; Mathieu, P.; Chelladurai, B.; Yin, X.M.; Kessel, D. (2002). Release of cytochrome $\mathrm{c}$ and activation of procaspase-9 following lysosomal damage involves Bid cleavage. Cell Death and Differentiation, Vol.9, No.9 (September 2002), pp. 934-944

Ricchelli, F.; Jori, G.; Moreno, G.; Vinzens, F.; Salet, C. (1990). Factors influencing the distribution pattern of porphyrins in cell membranes. Journal of Photochemistry and Photobiology. B, Biology, Vol.6, No.1-2 (June 1990), pp. 69-77, ISSN 1011-1344

Robertson, C.A.; Hawkins, D.; \& Abrahamse, E.H. (2009). Photodynamic therapy (PDT): A short review on cellular mechanisms and cancer research applications for PDT. Journal of Photochemistry and Photobiology. B, Biology, Vol.96, No.1, pp. 1-8, ISSN 1011-1344

Roland, C.L.; Harken, A.H.; Sarr, M.G.; Barnett, C.C. (2007). Evidence-based surgical hypothesis: ICAM-1 expression determines malignant potential of cancer. Surgery, Vol.141, No.6 (June 2007), pp. 705-707, ISSN 0039-6060

Ryter, S.W.; Kim, H.P.; Hoetzel, A.; Park, J.W.; Nakahira, K.; Wang, X.; \& Choi, A.M.K. (2007). Mechanisms of cell death in oxidative stress. Antioxidant $\mathcal{E}$ Redox signaling, Vol.9, No.1, pp. 49-89, ISSN 1523-0864

Saczko, J.; Kulbacka, J.; Chwiłkowska, A ; Drąg-Zalesińska, M.; Wysocka, T.; Ługowski, M.; \& Banaś, T. (2005). The influence of photodynamic therapy on apoptosis in human melanoma cell line. Folia Histochemica et Cytobiologica, Vol.43, No.3, pp. 129-132, ISSN 0239-8508

Saczko, J.; Kulbacka, J.; Chwilkowska, A.; Pola, A.; Lugowski, M.; Marcinkowska, A.; Malarska, A. \& Banas, T. (2007). Cytosolic superoxide dismutase activity after photodynamic therapy, intracellular distribution of Photofrin II and hypericin, and P-glycoprotein localization in human colon adenocarcinoma. Folia Histochemica et Cytobiologica, Vol. 45, No. 2, pp. 93-97, ISSN 0239-8508

Saczko, J.; Kulbacka, L.; Chwiłkowska, A.; Ługowski, M..; Banaś, T. (2007). The response of malignant cells on photodynamic treatment. In: Aspects of photodynamic medicine, $\mathrm{H}$. Podbielska, A. Sieron, W. Stręk (Ed.), 47-56, Kriotechnika Medyczna, Wrocław

Saczko, J.; Mazurkiewicz, M.; Chwilkowska, A.; Kulbacka, J.; Kramer, G.; Lugowski, M.; Snietura, M.; Banas, T. (2007). Intracellular distribution of Photofrin in malignant and normal endothelial cell lines. Folia Biologica, Vol.53, No.1, pp. 7-12, ISSN 00155500

Saczko, J.; Skrzypek, W.; Chwiłkowska, A.; Choromańska, A.; Poła, A.; Gamian, A.; \& Kulbacka, J. (2009). Photo-oxidative action in cervix carcinoma cells induced by HpD-mediated photodynamic therapy. Experimental Oncology, Vol.31, No.4, pp. 195-199, ISSN 0204-3564

Santiard, D., Ribiere, C., Nordmann, R., Houee-Levin, C. (1995). Inactivation of $\mathrm{Cu}, \mathrm{Zn}$-superoxide dismutase by free radicals derived from ethanol metabolism: a gamma radiolysis study. Free Radicals in Biology and Medicine, 19: 121-127, ISSN: 0891-5849

Sheu, SS.; Nauduri, D.; \& Anders, M.W. (2006). Targeting antioxidants to mitochondria: A new therapeutic direction. Biochimica et Biophysica Acta, Vol.1762, No.2, pp. 256-265, ISSN 0006-3002 
Shevchuk, I.N.; Chekulayev, V.A.; \& Chekulayeva, L.V. (2002). The role of lipid peroxidation and protein degradation in the photodestruction of Ehrlich ascites carcinoma cells sensitized by hematoporphyrin derivative. Experimental Oncology, Vol.24, pp. 216-224, ISSN 0204-3564

Sieroń, A.; \& Adamek, M. (1999). Nowe oblicze światłolecznictwa - diagnostyka fluorescencyjna i fotochemoterapia cz.I. Chirurgia Polska, 1, 2, 91-99, pp. 91-178, ISSN 1507-5524

Sies, H.; Stahl, W.; \& Sundguist, A.R. (1992). Antioxidant functions of vitamins. Vitamin E and $C$, beta-carotene and other carotenoids. Annals of the New York Academy of Sciences, Vol.669, pp. 7-20, ISSN 0077-8923

Smith, R.P. (2002) Photodynamic therapy. Current Problems in Cancer, Vol.26, No.2 (MarchApril 2002), pp. 67-108, ISSN 0147-027

Szurko, A.; Krämer-Marek, G.; Widel, M.; Ratuszna, A.; Habdas, J.; Kus, P. (2003). Photodynamic effects of two water soluble porphyrins evaluated on human malignant melanoma cells in vitro. Acta Biochimica Polonica, Vol. 50, No.4, pp. 11651174, ISSN 0001-527X

Tardivo, J.P.; Giglio, A.D.; Oliveira, C.S.; Gabriellib, D.S.; Junqueirab, H.C.; Tadab, D.B.; Severinob, D.; Turchiellob, R.F.; Baptista, M.S. (2005). Methylene blue in photodynamic therapy: from basic mechanisms to clinical applications. Photodiagnosis and Photodynamic Therapy, Vol.2, No.3 (November 2005), pp. 175-91, ISSN 1572-1000

Wang, H.P.; Hanlon, J.G.; Rainbow, A.J.; Espiritu, M.; \& Singh, G. (2002). Up-regulation of Hsp27 plays a role in the resistance of human colon carcinoma HT29 cells to photooxidative stress. Photochemistry and Photobiology, Vol.76, No.1, pp.98-104, ISSN 0031-8655

Wang, X.; Ryter, S.W.; Dai, C.; Tang, Z.L.; Watkins, S.C.; Yin, X.M.; Song, R.; \& Choi, A.M. (2003). Necrotic cell death in response to oxidant stress involves the activation of the apoptogenic caspase-8/bid pathway. Journal of Biological Chemistry, Vol.278, No.31, pp. 29184-29191, ISSN 0021-9258

Woodburn, K.W.; Fan, Q., Kessel, D.; Luo, Y.; Young, S.W. (1998). Photodynamic therapy of B16F10 murine melanoma with lutetium texaphyrin. Journal of Investigative Dermatology, Vol.110 (January 1998), pp. 746-751, ISSN 0022-202X

Woodburn, K.W.; Fan, Q.; Milesm, D.R., Kessel, D.; Luo, Y.; Young S.W. (1998). Localization and efficacy analysis of the phototherapeutic lutetium texaphyrin (PCI-0123) in the murine EMT6 sarcoma model. Photochemistry and Photobiology, Vol.65, No.3 (January 2008), pp. 410-415, ISSN 0031-8655

Woods, J.A.; Traynor, N.J.; Brancaleon, L.; \& Moseley, H. (2004). The effect of photofrin on DNA strand breaks and base oxidation in HaCaT keratinocytes: a comet assay study. Photochemistry and Photobiology, Vol.79, No.1, pp. 105-113, ISSN 0031-8655

Zhang, W.G.; Li, X.W.; Ma, L.P.; Wang, S.W.; Yang, H.Y.; Zhang, Z.Y. (1999). Wild-type p53 protein potentiates phototoxicity of 2-BA-2-DMHA in HT29 cells expressing endogenous mutant p53. Cancer Letters, Vol.138, No.1 (April 1999), pp. 189-195, ISSN 0304-3835

Zhen-hui Peng, M.P.; Xiao, S.; Ren, J.; Liu, Y.; Li, X.; Li, Z. (2008). Apoptotic effect and mechanisms of AHPN on human skin malignant melanoma cells. Journal of Nanjing Medical University, Vol. 22, No.1 (January 2008), pp. 18-22 


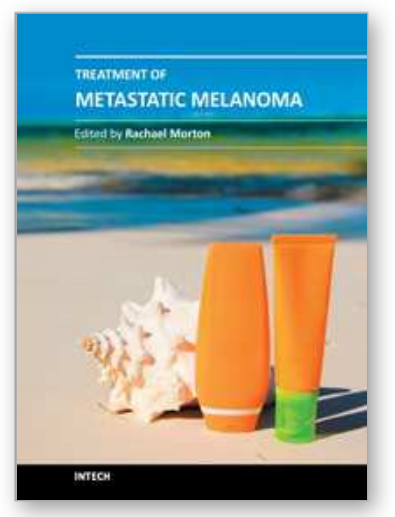

\author{
Treatment of Metastatic Melanoma \\ Edited by Ms Rachael Morton
}

ISBN 978-953-307-574-7

Hard cover, 348 pages

Publisher InTech

Published online 03, October, 2011

Published in print edition October, 2011

Surgery continues to be the mainstay treatment for melanoma localized to the primary tumor and/or lymph nodes. Results from randomized controlled trials indicate that sentinel node biopsy for the treatment of cutaneous melanoma of intermediate thickness has a beneficial effect on recurrence rates, and adjuvant radiotherapy to regional lymph node fields following surgical resection reduces loco-regional recurrence in patients at high risk of relapse. Isolated limb perfusion, electrochemotherapy, and photodynamic therapy continue to be evaluated for treatment of stage IV disease. However, the greatest excitement in new treatment has been with targeted therapies for genetic mutations. In particular, the promising results of partial and complete tumor response in stage IV disease from early phase trials of the B-RAF kinase inhibitors. This book provides a contemporary insight into the therapeutic treatment options for patients with metastatic melanoma and is relevant to clinicians and researchers worldwide. In addition, an update on current clinical trials for melanoma treatment has been included, and two chapters have been reserved to discuss the treatment of oral and uveal melanoma.

\title{
How to reference
}

In order to correctly reference this scholarly work, feel free to copy and paste the following:

Anna Choromańska, Julita Kulbacka, Agnieszka Chwiłkowska, Nina Skołucka, Andrzej Gamian and Jolanta Saczko (2011). Can Photodynamic Therapy Be an Alternative Method in Melanoma Treatment?, Treatment of Metastatic Melanoma, Ms Rachael Morton (Ed.), ISBN: 978-953-307-574-7, InTech, Available from: http://www.intechopen.com/books/treatment-of-metastatic-melanoma/can-photodynamic-therapy-be-analternative-method-in-melanoma-treatment-

\section{INTECH}

open science | open minds

\section{InTech Europe}

University Campus STeP Ri

Slavka Krautzeka 83/A

51000 Rijeka, Croatia

Phone: +385 (51) 770447

Fax: +385 (51) 686166

www.intechopen.com

\section{InTech China}

Unit 405, Office Block, Hotel Equatorial Shanghai

No.65, Yan An Road (West), Shanghai, 200040, China

中国上海市延安西路65号上海国际贵都大饭店办公楼 405 单元

Phone: +86-21-62489820

Fax: +86-21-62489821 
(C) 2011 The Author(s). Licensee IntechOpen. This is an open access article distributed under the terms of the Creative Commons Attribution 3.0 License, which permits unrestricted use, distribution, and reproduction in any medium, provided the original work is properly cited. 